\title{
29. K-Ar MINIMUM AGE FOR MEIJI GUYOT, EMPEROR SEAMOUNT CHAIN
}

\author{
G. Brent Dalrymple and Marvin A. Lanphere, U. S. Geological Survey, Menlo Park, California \\ and \\ James H. Natland, Deep Sea Drilling Project, Scripps Institution of Oceanography, La Jolla, California
}

\begin{abstract}
Conventional $\mathrm{K}-\mathrm{Ar}$ and ${ }^{40} \mathrm{Ar} /{ }^{39} \mathrm{Ar}$ age data on altered basalts from DSDP Hole 192A on Meiji Guyot, Emperor Seamount chain, indicate a minimum age for the volcano of $61.9 \pm 5.0 \mathrm{~m} . \mathrm{y}$. The $\mathrm{K}-\mathrm{Ar}$ data are consistent with the early Maestrichtian date of the overlying sediments, but do not provide either a positive or negative test of the hypothesis that Meiji is older than Emperor volcanoes to the south. The most prominent alteration affecting the age measurements is potassium metasomatism, particularly of feldspar phenocrysts. The K-Ar apparent ages of feldspar separates from the Meiji basalts show that more than half of the potassium metasomatism occurred within the last $25 \mathrm{~m} . \mathrm{y}$. or so, and that if the potassium replacement rate has been constant, then the alteration of the Meiji basalts did not begin for 10 to 20 m.y. after the volcano formed.
\end{abstract}

\section{INTRODUCTION}

Meiji Guyot is located beneath a thick hemipelagic sediment blanket in $\mathbf{3 0 0 0}$ meters of water at the northern end of the Emperor Seamount chain near the confluence of the Aleutian and Kuril trenches (Figure 1). Although there is a possibility that north of $52^{\circ} \mathrm{N}$ latitude the Emperor chain bends northeast and disappears into the Aleutian Trench (Jackson et al., 1972), it is generally thought that it bends northwest and that Meiji is the northernmost guyot in the chain. The age of the crust in the vicinity of Meiji is poorly known, but on the basis of magnetic anomaly patterns (Hilde et al. 1970) and the age of the sediments atop Meiji (Worsley, 1973), it was probably laid down in the Late Cretaceous. Recent paleomagnetic data (Marshall, 1978) show that Meiji formed at a latitude of $19^{\circ} \pm 3.6^{\circ}$; this strengthens the hypothesis that Meiji volcano is part of the HawaiianEmperor volcanic chain and that it formed over a hot spot near the present latitude of Hawaii (Morgan, 1972).

It is now known from radiometric data that the Hawaiian chain of volcanoes becomes progressively older to the northwest away from the active volcanoes of Kilauea and Mauna Loa on the island of Hawaii, and that the Hawaiian-Emperor bend is about $43 \mathrm{~m}$.y. old (see recent summaries in Dalrymple and Clague, 1976; Dalrymple et al., 1977). Recent K-Ar data from Leg 55 drilling (Dalrymple, Lanphere, and Clague, this volume) have shown that the age progression continues northward along the Emperor chain at least as far as Suiko Seamount $(64.7 \pm 1.1 \mathrm{~m} . \mathrm{y}),. 1350 \mathrm{~km}$ north of the Hawaiian-Emperor bend. From Suiko northward there are no radiometric data.

Meiji Seamount was drilled on Leg 19 of the Deep Sea Drilling Project, and Hole 192A penetrated 13

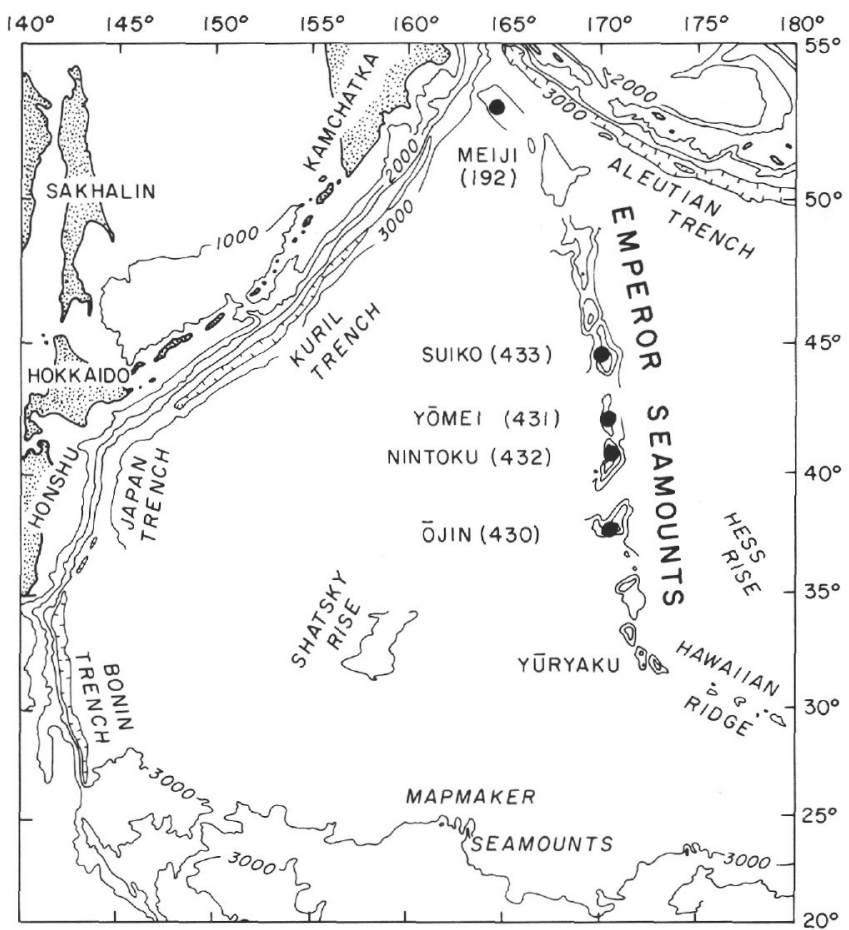

Figure 1. Index map of the northwest Pacific Ocean, showing the location of DSDP Site 192 on Meiji Guyot, Emperor Seamount chain. Leg 55 sites are also shown. Bathymetry is in fathoms.

meters into altered basalt. The basalt at Site 192 is overlain by 1044 meters of sediment, primarily diatomaceous clay, diatom ooze, chalk, and claystone, ranging from Pleistocene to Upper Cretaceous (Creager, Scholl, et al., 1973). The oldest sediments above the basalt contain a diverse lower Maestrichtian nannoflora (Worsley, 
1973), indicating that Meiji Seamount is at least 68 to 70 m.y. old (van Hinte, 1976).

The basalts of Hole 192A are much too altered to give reliable radiometric ages by conventional wholerock $\mathrm{K}-\mathrm{Ar}$ dating. Because of the importance of Meiji as possibly the northernmost Emperor volcano, however, we attempted to obtain a radiometric age using a combination of conventional whole-rock $\mathrm{K}-\mathrm{Ar}$, conventional feldspar $\mathrm{K}-\mathrm{Ar}$, and whole-rock ${ }^{40} \mathrm{Ar} /{ }^{39} \mathrm{Ar}$ incremental heating techniques, even though the extensive alteration made total success highly improbable.

\section{DESCRIPTION OF THE BASALT}

Five flows of extrusive basalt, ranging in thickness from 0.35 to 8.4 meters, were cored in Hole 192A. All the flows appear to be pillow basalts with glassy margins and coarser diabasic interiors, indicating that they were extruded beneath the sea (Natland and Stewart, 1973). The flows are highly altered and contain abundant secondary clay minerals, calcite, and iron oxides. The calcic cores of many of the plagioclase phenocrysts are replaced to varying degrees by K-feldspar with the optical properties of sanidine. This feldspar contains as much as 99 per cent orthoclase by composition, with only trace amounts of $\mathrm{Na}_{2} \mathrm{O}$ and $\mathrm{CaO}$ (Stewart et al., 1973). This replacement is probably due to K-rich alkaline solutions produced during alteration of the basalts (Stewart et al., 1973), and was also found in basalt of Hole 165 (Bass et al., 1973). In many parts of the core, the K-feldspar has in turn been replaced by clays.

The extensive alteration makes classification of the basalts very difficult. Stewart et al. (1973) list one chemical analysis of a basalt from Hole 192A (Sample $5-6,1-10 \mathrm{~cm}$ ). This analysis clearly shows the effects of alkali metasomatism: $\mathrm{K}_{2} \mathrm{O}$ content is 2.0 per cent. The chemical and microprobe data reported give contradictory indications on the composition of the basalts. On the one hand, because of the alkali enrichment, the basalt analysis plots in the alkalic field of Macdonald's (1968) alkali-silica diagram for Hawaiian basalts. On the other hand, the basalt has trace-element characteristics of either an island-edifice tholeiite ( $\mathrm{Zr}-\mathrm{Sr}$ relationship, after Bass, 1971) or a mid-ocean ridge tholeiite (Zr-Y-Ti relationship, after Cann and Heath, 1976). None of these inter-element relationships can be considered definitive, because only semi-quantitative $( \pm 15 \%)$ trace-element data were obtained. Also, the stability of $\mathrm{Sr}$ during alteration is questionable in view of the alkalifeldspar replacement of plagioclase, and $\mathrm{Zr}$ and other incompatible elements might have been affected by the total transformation of interstitial material to clays.

In an attempt to avoid these problems, we have analyzed a near-glassy portion of a pillow in Core 5 for both major oxides and trace elements (Table 1). The sample was selected because thin-section examination had shown no sign of the otherwise pervasive replacement of plagioclase by K-feldspar, probably because of the low permeability of this fine-grained portion of the
TABLE 1

Chemical Analyses of Basalt from Hole 192A, Meiji Guyot (Oxides in wt. \%, Ba and $\mathrm{Zr}$ in ppm)

\begin{tabular}{|c|c|c|c|}
\hline & \multicolumn{2}{|c|}{ Sample 5-1, 119-121 cm } & \\
\hline & as received & normalized to $100 \%$ & \\
\hline $\mathrm{SiO}_{2}$ & 44.8 & 50.9 & \\
\hline $\mathrm{Al}_{2} \mathrm{O}_{3}$ & 13.81 & 15.69 & \\
\hline $\mathrm{FeO}$ & 12.01 & 13.65 & \\
\hline $\mathrm{MgO}$ & 2.53 & 2.88 & \\
\hline $\mathrm{CaO}$ & 10.45 & 11.88 & \\
\hline $\mathrm{Na}_{2} \mathrm{O}$ & 1.50 & 1.70 & \\
\hline $\mathrm{K}_{2} \mathrm{O}$ & 0.61 & 0.69 & \\
\hline $\mathrm{TiO}_{2}$ & 2.00 & 2.27 & \\
\hline $\mathrm{P}_{2} \mathrm{O}_{5}$ & 0.17 & 0.19 & \\
\hline $\mathrm{MnO}$ & 0.12 & 0.14 & \\
\hline \multirow[t]{4}{*}{ Totals } & 88.00 & 99.99 & \\
\hline & & & Trace-Element \\
\hline & & & Standard Error \\
\hline & & & on Calibration (ppm) \\
\hline $\mathrm{Ba}$ & 70 & 79 & 5 \\
\hline $\mathrm{Zr}$ & 155 & 176 & 9 \\
\hline $\mathrm{Sr}$ & 188 & 214 & 8 \\
\hline Y & 30 & 34 & 1.9 \\
\hline $\mathrm{Nb}$ & 10 & 11 & 2.8 \\
\hline $\mathrm{Rb}$ & 15 & 17 & 2.0 \\
\hline $\mathrm{Ti} / \mathrm{Y}$ & 399 & & \\
\hline $\mathrm{Ti} / \mathrm{Sr}$ & 64 & & \\
\hline $\mathrm{Zr} / \mathrm{Y}$ & 5.2 & & \\
\hline $\mathrm{Zr} / \mathrm{Sr}$ & 0.82 & & \\
\hline $\mathrm{Nb} / \mathrm{Zr}$ & 0.65 & & \\
\hline $\mathrm{Ti} / \mathrm{Zr}$ & 77 & & \\
\hline
\end{tabular}

core. Trace elements were analyzed by $\mathrm{X}$-ray fluorescence techniques, and include elements $\mathrm{Zr}, \mathrm{Y}, \mathrm{Nb}$, and probably Sr) which, along with $\mathrm{TiO}_{2}$, appear to resist mobilization even during extensive alteration (e.g., Cann, 1970; Wood et al., 1976), and which are especially useful for basalt classification. Trace elements were corrected for matrix effects and instrumental interferences following the method of Bougault et al. (1977). Corrections for elemental interferences ( $\mathrm{Zr}$ for Sr, Y for $\mathrm{Rb}, \mathrm{Nb}$ for $\mathrm{Y}$ ) were made following procedures discussed in Cann (1970) and detailed in a private document provided courtesy of J. R. Cann. The sample was calibrated to both USGS and French international Reference standards (Flanagan, 1973). Standard errors on the corrected trace element calibrations are listed on Table 1.

Although the sample did not experience extensive $\mathrm{K}$-metasomatism, it is riddled with clay patches and is intensely oxidized and hydrated. Secondary calcite also occurs. Therefore, it is virtually certain that $\mathrm{MgO}$ and $\mathrm{CaO}$ are not at their original concentrations, and the major oxide-summation is low. There is also probably some $\mathrm{K}_{2} \mathrm{O}$ enrichment in the clays. $\mathrm{TiO}_{2}$ content is still fairly low $(2 \%)$, and $\mathrm{K}_{2} \mathrm{O}$ is much lower than in the analysis originally reported by Stewart et al. (1973). The sample has sufficiently low total alkali content to be a tholeiite, according to the classification of Macdonald (1968). The mobile trace elements, $\mathrm{Rb}$ and $\mathrm{Ba}$, are also 
low. Consideration of the ratios of the elements which are stable during alteration leads to the following conclusions:

1) On the basis of $\mathrm{Ti} / \mathrm{Y}$ and $\mathrm{Zr} / \mathrm{Y}$ ratios, the basalt falls in the field of "within-plate basalts" of Cann and Heath (1976).

2) On the basis of $\mathrm{Ti} / \mathrm{Sr}$ and $\mathrm{Zr} / \mathrm{Sr}$ relationships, the basalt falls in the field of ocean floor basalts of Cann and Heath (1976).

3) The ratio $\mathrm{Nb} / \mathrm{Zr}$ is elevated, compared with typical depleted mid-ocean ridge basalts, but is similar to less depleted Reykjanes Ridge basalts (Wood et al., 1979).

In all likelihood, then, the Meiji seamount basalts of Site 192 were island-edifice tholeiites, and thus probably represent the shield-building stage of Meiji volcanism. This verifies the conclusion based on trace elements of Stewart et al. (1973).

In Stewart et al. (1973), some stress was placed on the clinopyroxene analysis as a criterion for basalt identification. As indicated in that paper, the clinopyroxene phenocrysts are unusually calcic, and in that respect comparable to clinopyroxenes in some oceanic island alkalic suites (cf. Maui: Fodor et al., 1975). By the criteria of LeBas (1962), the Meiji basalt clinopyroxene phenocrysts resemble those of tholeiitic suites in terms of $\mathrm{Ti}$ and $\mathrm{Al}$, whereas the groundmass pyroxene compositions (to LeBas, the most definitive test) resemble those of alkalic basalts.

Recent analyses of clinopyroxenes from the ocean floor tholeiite suite (Donaldson et al., 1976) indicated that high $\mathrm{Ca}$ content is not necessarily an indication of alkalic parentage. More important, groundmass clinopyroxenes in sea-floor extrusive basalts have highly variable compositions because they formed under disequilibrium conditions and can have skeletal or dendritic morphologies. They are thus not easy targets for an electron microprobe. The Meiji groundmass clinoproxene analyses given in Stewart et al. (1973), reflect these ambiguities, and thus may not be diagnostic of the parentage of the basalts.

At this time, the weight of evidence suggests that the Meiji basalts were originally tholeiitic, although alteration makes accurate determination of their original chemistry difficult.

\section{SAMPLES DATED}

Basalt samples from six intervals within the thickest basalt flow cored (Unit 2, 0.35 to $8.4 \mathrm{~m}$ ) were selected for study. All are from Core 5, Hole 192A. Three of the samples were fairly large $(5-2,37-42 \mathrm{~cm} ; 5-3,41-48 \mathrm{~cm}$; and 5-6, 56-62.5 cm), allowing feldspar fractions to be separated from them. The other samples $(5-2,125-$ $126 \mathrm{~cm} ; 5-4,100-101 \mathrm{~cm}$, and 5-5, 70-71 cm) were used for whole-rock determinations.

The samples were selected from the least altered portions of the core. Zones of intense alteration up to $5 \mathrm{~cm}$ wide border almost all cracks throughout the rock. The larger cracks are typically filled with calcite and reddish iron oxides, and are spaced at 10 to $30 \mathrm{~cm}$ intervals. Thin-section examination reveals that alteration to smectites and replacement of calcic plagioclase with alkali feldspars and clays is most intense in these zones. In hand specimen, each sample selected appeared about equally altered, but none was as intensely altered as zones next to cracks.

Phenocrysts of plagioclase are more typically transformed to alkali feldspar than is groundmass plagioclase. Therefore, samples were selected that were fairly coarse grained (coarsely sub-ophitic to ophitic textures), to facilitate separation of least-altered feldspars. The principal differences among the samples selected for dating are not mineralogical. All are sparsely plagioclase-clinopyroxene phyric basalts with abundant groundmass plagioclase and clinopyroxene and virtually no (altered) olivine. Grain size, however, varies from medium to coarse grained; the samples from Sections 3 and 4 have diabasic textures. All samples, however, contain between 20 and 40 per cent of generally altered interstitial matrix. This material probably was once mainly glass with opaque minerals and spherulitic or dendritic projections from the larger crystals, mainly clinopyroxene; it is now entirely replaced by clays and calcites. In the samples selected, especially those with diabasic textures, these clays can be seen in hand specimen as small ( 1 to $2 \mathrm{~mm}$ ) dark lumps highlighted by the surrounding white feldspars.

The problem of age determination in these samples was therefore twofold. First, the effects of the altered mesostasis had to be minimized. Consequently, feldspar separation was necessary. Second, the effects of authigenic K-feldspar replacing plagioclase had to be minimized (by selecting least-altered samples) and, if not altogether eliminated, quantitatively assessed. As we shall show, we can only derive a minimum age for Meiji Guyot from our data, but we can put time constraints on the formation of the authigenic alkali feldspars.

\section{K-Ar TECHNIQUES}

Samples for whole-rock analysis were either sawed (conventional) or cored $\left({ }^{40} \mathrm{Ar} /{ }^{39} \mathrm{Ar}\right)$ in fresh water. A portion of each sample was crushed to less than $100 \mu \mathrm{m}$ for the $\mathrm{K}_{2} \mathrm{O}$ measurement. Feldspar in several size ranges ( 44 to $63 \mu \mathrm{m}, 63$ to $105 \mu \mathrm{m}, 105$ to $149 \mu \mathrm{m}$ ) was separated from three sample intervals using ceramic crushing equipment, stainless steel sieves, and a Frantz magnetic separator. The feldspar concentrates were leached in dilute HF to remove adhering glass, clay, and other mineral fragments, and in 10 per cent $\mathrm{HCl}$ to remove calcite. Final cleaning was done in distilled water, using an ultrasonic cleaner.

Conventional Ar measurements were made by isotope dilution mass spectrometry, using techniques and equipment described by Dalrymple and Lanphere (1969). Potassium was measured for the whole-rock samples by flame photometry, using lithium metaborate fusion (Ingamells, 1970), and for the feldspar concentrates using isotope dilution with a mixed ${ }^{40} \mathrm{~K}-{ }^{41} \mathrm{~K}$ tracer.

For the ${ }^{40} \mathrm{Ar} /{ }^{39} \mathrm{Ar}$ measurements, small cores $1 \mathrm{~cm}$ long by $0.6 \mathrm{~cm}$ diameter and weighing 0.6 to 0.7 grams were sealed in air in fused silica vials and irradiated at 1 megawatt for 25 to 30 hours in the core of the U. S. Geological Survey TRIGA reactor, where they received 
a neutron dose of $2.5 \times 10^{18}$ to $3.0 \times 10^{18}$ nvt. The irradiation procedures, reactor flux characteristics, fluence monitor minerals, corrections for interfering argon isotopes, data reduction and error estimating procedures, and incremental heating techniques are described by Dalrymple and Lanphere $(1971,1974)$, Lanphere and Dalrymple (1971), and Dalrymple et al. (in press).

\section{RESULTS AND DISCUSSION}

The total fusion $\mathrm{K}-\mathrm{Ar}$ and ${ }^{40} \mathrm{Ar} /{ }^{39} \mathrm{Ar}$ results (Table 2) clearly show the effects of the potassium metasomatism on the K-Ar system. For both the whole-rock and the feldspar samples, the calculated ages generally, though not always, decrease with increasing $\mathrm{K}_{2} \mathrm{O}$ content. The $\mathrm{K}_{2} \mathrm{O}$ content in the basalts ranges from 0.75 to 2.1 per cent. The oldest whole-rock $\mathrm{K}-\mathrm{Ar}$ ages are from Samples 5-2, 37-38 cm and 5-3, 41-42 cm, which have $\mathrm{K}_{2} \mathrm{O}$ contents of about 0.9 per cent and ages of 51 to 52 m.y. The $\mathrm{K}_{2} \mathrm{O}$ contents in the feldspar concentrates range from 0.12 to 7.0 per cent, and the ages from 62 to 22 m.y. X-ray diffractometer analyses show that all the feldspar separates are mixtures of sanidine and plagioclase. The X-ray patterns of feldspars from Section 5-6, which have about 7 per cent $\mathrm{K}_{2} \mathrm{O}$, show a large portion (estimated 50 to $75 \%$ ) of sanidine, whereas the X-ray patterns of the feldspars from Section 5-2, which have only 0.1 to 0.2 per cent $\mathrm{K}_{2} \mathrm{O}$, show only a slight trace of sanidine.

The feldspar K-Ar results can be interpreted as simple mixing of two phases, each with a different apparent $\mathrm{K}-\mathrm{Ar}$ age. We have calculated the effect of such mixing by assuming that the plagioclase has a $\mathrm{K}_{2} \mathrm{O}$ content of
0.1 per cent and an age of $70 \mathrm{~m} . \mathrm{y}$. , and the K-feldspar a $\mathrm{K}_{2} \mathrm{O}$ content of 10 per cent. The resulting curves, showing the change in the apparent $\mathrm{K}-\mathrm{Ar}$ age of the mixture as a function of the $\mathrm{K}_{2} \mathrm{O}$ content (and per cent of $\mathrm{K}$-feldspar) of the mixture, are shown in Figure 2 for various K-feldspar apparent ages. The calculations show that the apparent ages of such plagioclase $\mathrm{K}$-feldspar mixtures are most sensitive to the apparent age of the $\mathrm{K}$-feldspar, and relatively insensitive to the age of the plagioclase or the $\mathrm{K}_{2} \mathrm{O}$ contents of either the plagioclase or the K-feldspar. Curves calculated for a $\mathrm{K}$-feldspar $\mathrm{K}_{2} \mathrm{O}$ content of 7 per cent, for example, almost exactly overlie those of Figure 2, and the effect of doubling or halving the plagioclase $\mathrm{K}_{2} \mathrm{O}$ content shifts the curves only slightly to the right or left, respectively. The figure shows that for feldspar mixtures with $\mathrm{K}_{2} \mathrm{O}$ contents above about 2 per cent, the apparent age of the mixture is essentially the apparent age of the K-feldspar.

The feldspar K-Ar data from Table 2 indicate that the apparent ages of the K-feldspars are 22 to 28 m.y. The whole-rock ages are also strongly influenced by the apparent age of the replacement K-feldspar, but they are nearly impossible to model in any realistic way because of complications arising from the uncertainty and variation of the initial $\mathrm{K}_{2} \mathrm{O}$ contents of the flow, the presence of K-bearing clay minerals, and argon loss from the clays and possibly from other interstitial phases.

The apparent K-Ar ages of K-feldspar probably do not represent time elapsed since crystallization, but are most likely averages that reflect the time-integrated history of the K-feldspar replacement. Even so, the data provide some valuable information about the time and

TABLE 2

Total Fusion K-Ar Age Data on Basalt and Feldspar from Meiji Guyot, Emperor Seamount Chain, Hole 192A

\begin{tabular}{|c|c|c|c|c|c|c|c|}
\hline \multirow{3}{*}{$\frac{\begin{array}{c}\text { Sample } \\
(\text { Interval in } \mathrm{cm})\end{array}}{5-2,37-38}$} & \multirow{2}{*}{\multicolumn{2}{|c|}{ Material }} & \multicolumn{5}{|c|}{ Argon } \\
\hline & & & $\begin{array}{l}\mathrm{K}_{2} \mathrm{O}^{\mathrm{a}} \\
(\text { wt. } \%)\end{array}$ & $\begin{array}{l}\text { Weight } \\
(\mathrm{g})\end{array}$ & \multirow{2}{*}{$\begin{array}{c}\begin{array}{c}40_{\mathrm{ArR}} \\
(\mathrm{mol} / \mathrm{g})\end{array} \\
6.607 \times 10^{-11}\end{array}$} & \multirow{2}{*}{$\begin{array}{c}{ }^{40} \mathrm{Ar}_{\mathrm{R}} \\
(\%) \\
71.1\end{array}$} & \multirow{2}{*}{$\begin{array}{c}\begin{array}{c}\text { Calculated Age } \\
\left(10^{6} \text { years }\right)\end{array} \\
52.0 \pm 1.6\end{array}$} \\
\hline & Basalt & & 0.870 & 2.419 & & & \\
\hline \multirow[t]{2}{*}{$37-42$} & Feldspa & ir $(44-63 \mu \mathrm{m})$ & $0.2306^{\mathrm{c}}(1)$ & 1.042 & 1.389 & 14.0 & $41.4 \pm 3.3$ \\
\hline & Feldspa & r $(63-105 \mu \mathrm{m})$ & $0.1189^{c}(1)$ & 1.001 & 1.078 & 8.8 & $61.9 \pm 5.0$ \\
\hline $125-126$ & Basalt & & 0.754 & 2.278 & 4.260 & 57.6 & $38.8 \pm 1.2$ \\
\hline $3,41-42$ & Basalt & & 0.908 & 2.754 & 6.806 & 74.6 & $51.3 \pm 1.5$ \\
\hline \multirow[t]{2}{*}{$42-48$} & Feldspa & $\mathrm{r}(63-105 \mu \mathrm{m})$ & $3.82^{\mathrm{C}} \quad$ (1) & 1.101 & 13.82 & 85.4 & $25.0 \pm 0.8$ \\
\hline & Feldspa & Ir $(105-149 \mu \mathrm{m})$ & $5.19^{\mathrm{c}}$ & 1.066 & 19.92 & 91.1 & $26.5 \pm 0.8$ \\
\hline $4,100-101$ & Basalt & & 2.13 & 3.233 & 8.681 & 83.1 & $28.1 \pm 0.8$ \\
\hline $5,70-71$ & Basalt & & 2.06 & 2.198 & 7.794 & 73.5 & $26.0 \pm 0.8$ \\
\hline $6,56-57$ & Basalt & & 1.57 & 2.474 & 8.642 & 70.3 & $37.8 \pm 1.1$ \\
\hline \multirow{3}{*}{$57-62.5$} & Feldspa & $\mathrm{r}(63-105 \mu \mathrm{m})$ & $6.69 \mathrm{c}$ & 1.291 & 21.59 & 85.6 & $22.3 \pm 0.7$ \\
\hline & Feldspa & r $(105-149 \mu \mathrm{m})$ & $7.00^{\mathrm{c}}$ & 1.116 & 29.00 & 94.7 & $28.5 \pm 0.9$ \\
\hline & & \multicolumn{6}{|c|}{ 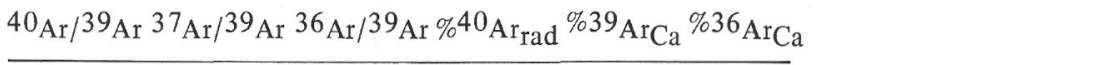 } \\
\hline $5-3,41-42$ & Basalt & 5.374 & 0.00 & 62. & 0.2 & 3.3 & $37.4 \pm 0.9^{d}$ \\
\hline \multicolumn{8}{|c|}{ 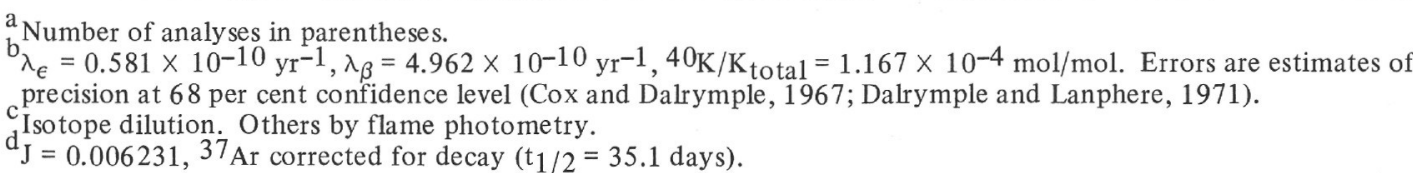 } \\
\hline
\end{tabular}




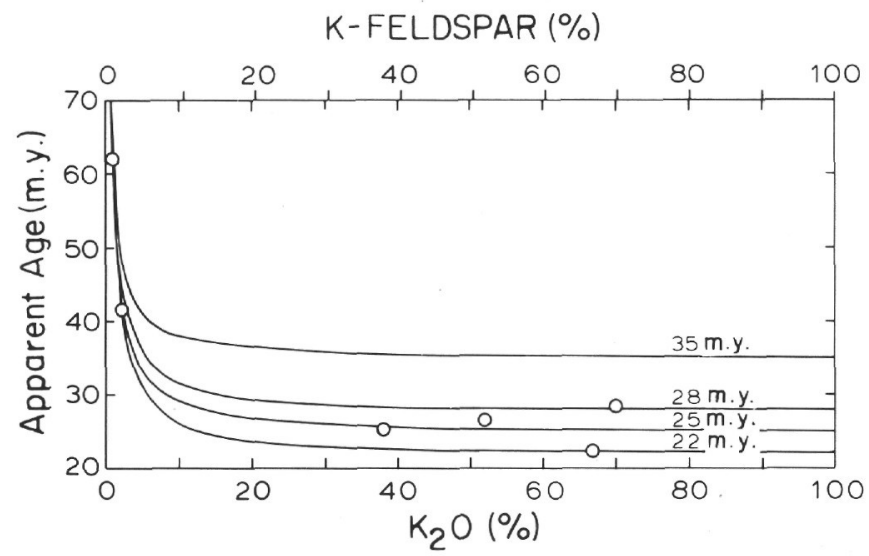

Figure 2. Effect on the apparent $K$-Ar age of mixing $K$-feldspar of various apparent ages $(22,25,28$, and 35 m.y.) with 70-m.y.-old plagioclase. The $\mathrm{K}_{2} \mathrm{O}$ contents used in the calculations were plagioclase 0.1 per cent, and K-feldspar 10 per cent. The circles are the feldspar data from Table 1.

duration of the potassium metasomatism. If the replacement has been continuous and at a constant rate over the last $70 \mathrm{~m} . \mathrm{y}$. , then the sanidine would have an apparent, or "average," age of $35 \mathrm{~m}$.y. The feldspar data (Table 2, Figure 2) indicate, however, that either the metasomatism began 10 to $20 \mathrm{~m}$.y. after the seamount formed or the rate of alteration has not been constant. It may be that the rate of alteration increased as Meiji accumulated a thick sediment blanket and that alteration continues today. In any event, it is clear that half of the $\mathrm{K}$-feldspar replacement in the basalts of Hole 192A took place within the last $25 \mathrm{~m}$.y. or so. Ozima et al. (1977) similarly have found that the addition of $\mathrm{K}$ to a sample of alkalic basalt dredged from Lamont Guyot occurred much later than the crystallization of the basalt. These results from seamounts differ from the findings of Hart and Staudigel (1978), who have shown that the alteration of $110-\mathrm{m} . \mathrm{y}$.-old mid-oceanic ridge basalts in DSDP Hole 418A took place within $30 \mathrm{~m} . \mathrm{y}$. of their formation.

All the data in Table 1 must be minimum ages, in view of the effect of the $\mathrm{K}$-feldspar and other alteration products on the measured ages. Even the greatest age of $61.9 \pm 5.0 \mathrm{~m} . \mathrm{y}$. must be considered a minimum age because the X-ray diffraction data show that K-feldspar is present in the feldspar concentrate, although only in trace amounts.

${ }^{40} \mathrm{Ar} /{ }^{39} \mathrm{Ar}$ incremental heating experiments were done on the two whole-rock samples with the greatest apparent ages (Table 3; Figure 3), to see if the age spectra would resolve the various age components. Not surprisingly, both age spectra indicate highly disturbed samples, and appear to be dominated by the replacement K-feldspar, by argon loss, or by both. The data do not show any linear correlation when plotted on an ${ }^{40} \mathrm{Ar} /{ }^{36} \mathrm{Ar}-{ }^{39} \mathrm{Ar} /{ }^{36} \mathrm{Ar}$ correlation diagram. There also is not any obvious direct or inverse correlation of $\mathrm{Ca}$ derived ${ }^{37} \mathrm{Ar}$ with radiogenic ${ }^{40} \mathrm{Ar}$ or apparent age; this indicates that the incremental heating did not resolve the apparent ages of $\mathrm{K}$-bearing (sanidine) and Ca-bearing feldspars (plagioclase).

The minimum K-Ar age of $61.9 \pm 5.0 \mathrm{~m} . \mathrm{y}$. is consistent with the early Maestrichtian date of the overlying sediments (Worsley, 1973). It is not significantly different, however, from the age of $64.7 \pm 1.1 \mathrm{~m} . \mathrm{y}$. for Suiko Seamount (Dalrymple, Lanphere, and Clague, this volume), and the Meiji K-Ar age data do not provide either a positive or negative test of the hypothesis that the Emperor chain becomes progressively older to the north of Suiko. The best minimum age for Meiji volcano is still about 68 to $70 \mathrm{~m} . \mathrm{y}$. (corresponding to early Maestrichtian time), determined by study of nannofossils in the overlying sediments.

\section{ACKNOWLEDGMENTS}

We thank A. Atkinson, S. J. Kover, B. M. Myers, and J. C. Von Essen for assistance with the argon measurements, L.B. Schlocker and A. L. Berry for the potassium measurements, R. J. May for the feldspar X-ray data, and R. Dokter and J. Saburomaru for the difficult and time-consuming feldspar separations. We also appreciate the helpful manuscript review of our colleagues J. L. Morton and D. W. Scholl.

\section{REFERENCES}

Bass, M. N., 1971. Variable abyssal basalt populations and their relation to sea-floor spreading rates, Earth Planet. Sci. Lett., v. 11, pp. 18-22.

Bass, M. N., Moberly, R., Rhodes, J. M., Shih, Chi-yu, and Church, S. E., 1973. Volcanic rocks cored in the central Pacific, Leg 17, Deep Sea Drilling Project. In Winterer, E. L., Erving, J. I., et al., Initial Reports of the Deep Sea Drilling Project, v. 17: Washington (U. S. Government Printing Office), pp. 429-503.

Bougault, H., Cambon, P., Toulhoat, H., 1977. X-ray spectrometric analysis of trace elements in rocks; correction for instrumental interferences, $X$-ray Spectrometry, v. 6, pp. 66-72.

Cann, J. R., 1970. Rb, Sr, Y, Zr, and Nb in some ocean floor basaltic rocks, Earth Planet. Sci. Lett., v. 10, pp. 7-11.

Cann, J. R. and Heath, R., 1976. Some trace elements in basalts from Leg 34. In Yeats, R. S., Hart, S. R., et al., Initial Reports of the Deep Sea Drilling Project, v. 34: Washington (U. S. Government Printing Office), pp. 289-292.

Cox, A. and Dalrymple, G. B., 1967. Statistical analysis of geomagnetic reversal data and the precision of potassiumargon dating, J. Geophys. Res., v. 72, pp. 2603-2614.

Creager, J. S., Scholl, D. W., et al., 1973. Initial Reports of the Deep Sea Drilling Project, v. 19: Washington (U. S. Government Printing Office).

Dalrymple, G. B., Alexander, E. C., Jr., Lanphere, M. A., and Kraker, G. P., in press. Irradiation of samples for ${ }^{40} \mathrm{Ar} /{ }^{39} \mathrm{Ar}$ dating using the Geological Survey TRIGA Reactor (GSTR), U. S. Geol. Survey Prof. Paper.

Dalrymple, G. B. and Clague, D. A., 1976. Age of the Hawaiian - Emperor bend, Earth Planet Sci. Lett., v. 31, pp. 313-329.

Dalrymple, G. B., Clague, D. A., and Lanphere, M. A., 1977. Revised age for Midway Volcano, Hawaiian Volcanic chain, Earth Planet. Sci. Lett., v. 37, pp. 107-116.

Dalrymple, G. B. and Lanphere, M. A., 1969. Potassiumargon dating: San Francisco (W. H. Freeman and Co.), 258 pp. 
TABLE 3

Analytical Data for ${ }^{40} \mathrm{Ar} /{ }^{39} \mathrm{Ar}$ Incremental Heating Experiments on Basalt from Meiji Guyot, Hole 192A

\begin{tabular}{|c|c|c|c|c|c|c|c|c|}
\hline $\begin{array}{l}\text { Temp. } \\
\left({ }^{\circ} \mathrm{C}\right)\end{array}$ & $40 \mathrm{Ar} /{ }^{39} \mathrm{Ar}$ & ${ }^{37} \mathrm{Ar} /{ }^{39} \mathrm{Ara}$ & ${ }^{36} \mathrm{Ar} /{ }^{39} \mathrm{Ar}$ & $\begin{array}{c}{ }^{39} \mathrm{Ar} \\
\text { (\% of total) }\end{array}$ & $\begin{array}{c}{ }^{40} \mathrm{Ar}_{\mathrm{R}} \\
(\%)\end{array}$ & $\begin{array}{c}{ }^{39} \mathrm{Ar} \mathrm{Ca} \\
(\%)\end{array}$ & $\begin{array}{c}{ }^{36} \mathrm{Ar}_{\mathrm{Ca}} \\
(\%)\end{array}$ & $\begin{array}{l}\text { Apparent Age } \\
\text { (106 years) }\end{array}$ \\
\hline \multicolumn{9}{|c|}{ Sample $5-2,37-38 \mathrm{~cm}(\mathrm{~J}=0.008263)$} \\
\hline 500 & 10.45 & 3.146 & 0.0236 & 36.3 & 35.6 & 0.2 & 3.6 & $54.8 \pm 3.3$ \\
\hline 600 & 9.46 & 13.60 & 0.0245 & 14.5 & 35.0 & 0.9 & 15.1 & $49.0 \pm 5.4$ \\
\hline 660 & 6.61 & 6.72 & 0.0138 & 11.1 & 46.5 & 0.4 & 13.3 & $45.4 \pm 11.9$ \\
\hline 730 & 6.89 & 3.174 & 0.0133 & 8.7 & 46.4 & 0.2 & 6.5 & $47.2 \pm 14.3$ \\
\hline 780 & 5.81 & 2.881 & 0.0138 & 5.3 & 33.4 & 0.2 & 5.7 & $28.8 \pm 31.0$ \\
\hline 840 & 5.23 & 4.078 & 0.0137 & 4.8 & 28.8 & 0.3 & 8.1 & $22.2 \pm 29.8$ \\
\hline 900 & 5.17 & 13.98 & 0.0157 & 5.7 & 31.8 & 0.9 & 24.2 & $24.6 \pm 34.1$ \\
\hline 1000 & 4.321 & 27.71 & 0.0140 & 11.6 & 55.6 & 1.8 & 53.8 & $36.1 \pm 18.1$ \\
\hline \multirow[t]{2}{*}{ Fusion } & 10.40 & 37.78 & 0.0517 & 1.9 & - & 2.4 & 19.8 & $-28.0 \pm 70.0$ \\
\hline & & & & $\overline{99.9}$ & & & & \\
\hline
\end{tabular}

Sample 5-3, 41-42 cm $(J=0.006321)$

\begin{tabular}{|c|c|c|c|c|c|c|c|c|}
\hline 500 & 8.15 & 3.091 & 0.0118 & 27.9 & 60.2 & 0.2 & 7.1 & $54.4 \pm 2.1$ \\
\hline 600 & 7.43 & 6.16 & 0.0205 & 6.5 & 24.9 & 0.4 & 8.2 & $20.7 \pm 6.8$ \\
\hline 700 & & & & & & & & \\
\hline$(\text { lost })^{\mathrm{c}}$ & - & - & - & (8.7) & - & - & - & - \\
\hline 800 & 5.20 & 1.454 & 0.00789 & 8.1 & 57.2 & 0.1 & 5.0 & $33.1 \pm 5.2$ \\
\hline 900 & 2.660 & 1.306 & 0.00281 & 26.8 & 72.6 & 0.1 & 12.7 & $21.6 \pm 1.9$ \\
\hline 1000 & 2.700 & 6.73 & 0.00437 & 21.0 & 72.0 & 0.4 & 41.9 & $21.8 \pm 2.9$ \\
\hline \multirow[t]{2}{*}{ Fusion } & 24.72 & 28.16 & 0.0837 & 1.0 & 9.1 & 1.8 & 9.2 & $26.0 \pm 55.0$ \\
\hline & & & & 00.0 & & & & \\
\hline
\end{tabular}

\footnotetext{
${ }_{b}^{\mathrm{a}}$ Corrected for ${ }^{37} \mathrm{Ar}$ decay $\left(\mathrm{t}_{1 / 2}=35.1\right.$ days $)$.

$\mathrm{b}_{\lambda_{\epsilon}}=0.581 \times 10^{-10} \mathrm{yr}^{-1}, \lambda_{\beta}=4.692 \times 10^{-10} \mathrm{yr}^{-1}$. Errors are estimates of precision at 68 per cent confidence

$\mathrm{c}_{\text {The fraction of }}{ }^{39} \mathrm{Ar}$ was calculated from the $40 \mathrm{Ar}_{\mathrm{rad}}$ in the remaining steps, the ${ }^{40} \mathrm{Ar}_{\mathrm{rad}} /{ }^{39} \mathrm{ArK}$ ratio in the adjacent increments, and the ${ }^{40} \mathrm{Ar}_{\text {rad }}$ in the conventional analysis.
}

1971. ${ }^{40} \mathrm{Ar} /{ }^{39} \mathrm{Ar}$ technique of $\mathrm{K}-\mathrm{Ar}$ dating: a comparison with the conventional technique, Earth Planet. Sci. Lett., v. 12, pp. 300-308.

1974. ${ }^{40} \mathrm{Ar} /{ }^{39} \mathrm{Ar}$ age spectra of some undisturbed terrestrial samples, Geochim. et Cosmochim. Acta, v. 38, pp. 715-738.

Donaldson, C. H., Brown, R. W., and Reid, A. M., 1976. Petrology and chemistry of basalts from the Nazca Plate: Part I - Petrography and mineral chemistry. In Yeats, R. S., Hart, S. R., et al., Initial Reports of the Deep Sea Drilling Project, v. 34: Washington (U. S. Government Printing Office), pp. 227-238.

Flanagan, F. J., 1973. 1972 values for international geochemical reference standards, Geochim. Cosmochim. Acta., v. 37, pp. 1189-1200.

Fodor, R. V., Keil, K., Bunch, T. E., 1975. Contributions to the mineral chemistry of Hawaiian rocks. IV Pyroxenes in rocks from Halekala and West Maui volcanoes, Maui, Hawaii, Contrib. Mineral Petrol. v. 50, pp. 173-195.

Hart, S. R. and Staudigel, H., 1978. Ocean Crust-seawater interaction: Leg 53, (abstract) EOS, v. 59, p. 409.

Hilde, T. W. C., Isezaki, N., and Wageman, J. M., 1976. Mesozoic sea-floor spreading in the North Pacific. In Sutton, G. H., Manghani, M. H., and Moberly, R. (Eds.), The Geophysics of the Pacific Ocean Basin and Its Margin: AGU Monograph 19, pp. 205-226.

Ingamells, C. O., 1970. Lithium metaborate flux in silicate analysis, Anal. Chim. Acta, v. 52, pp. 323-334.
Jackson, E. D., Silver E. A., and Dalrymple, G. B., 1972. Hawaiian-Emperor chain and its relation to Cenozoic circumpacific tectonics, Geol. Soc. America Bull., v. 83, pp. 601-618.

Lanphere, M. A. and Dalrymple, G. B., 1971. A test of the ${ }^{40} \mathrm{Ar} /{ }^{39} \mathrm{Ar}$ age spectrum technique on some terrestrial materials, Earth Planet. Sci. Lett., v. 12, pp. 350-372.

LeBas, M. J., 1962. The role of aluminum in igneous clinopyroxenes with relation to their parentage, Amer. Jour. Sci., v. 260, pp. 267-288.

Macdonald, G. A., 1968. Composition and origin of Hawaiian lavas, Geol. Soc. Amer. Mem. 116, pp. 477-522.

Marshall, Monte, 1978. The magnetic properties of some DSDP basalts from the North Pacific and inferences for Pacific Plate Tectonics, J. Geophys. Res., v. 83, pp. 289308.

Natland, J. H. and Stewart, R. J., 1973. Field relations and petrography of basalts, Hole 192A. In Creager, J. S., Scholl, D. W., et al., Initial Reports of the Deep Sea Drilling Project, v. 19: Washington (U. S. Government Printing Office), pp. 475-477.

Morgan, W. J., 1972. Plate motions and deep mantle convection. In Shagam, L. R., et al. (Eds.), Studies in Earth and Space Sciences (Hess Volume): Geol. Soc. America Mem. 132, pp. 7-22.

Ozima, M., Saito, K., and Honda, M., 1977. Sea water weathering effect on K-Ar age of submarine basalt, Geochim. et Cosmochim. Acta, v. 41, pp. 453-461. 


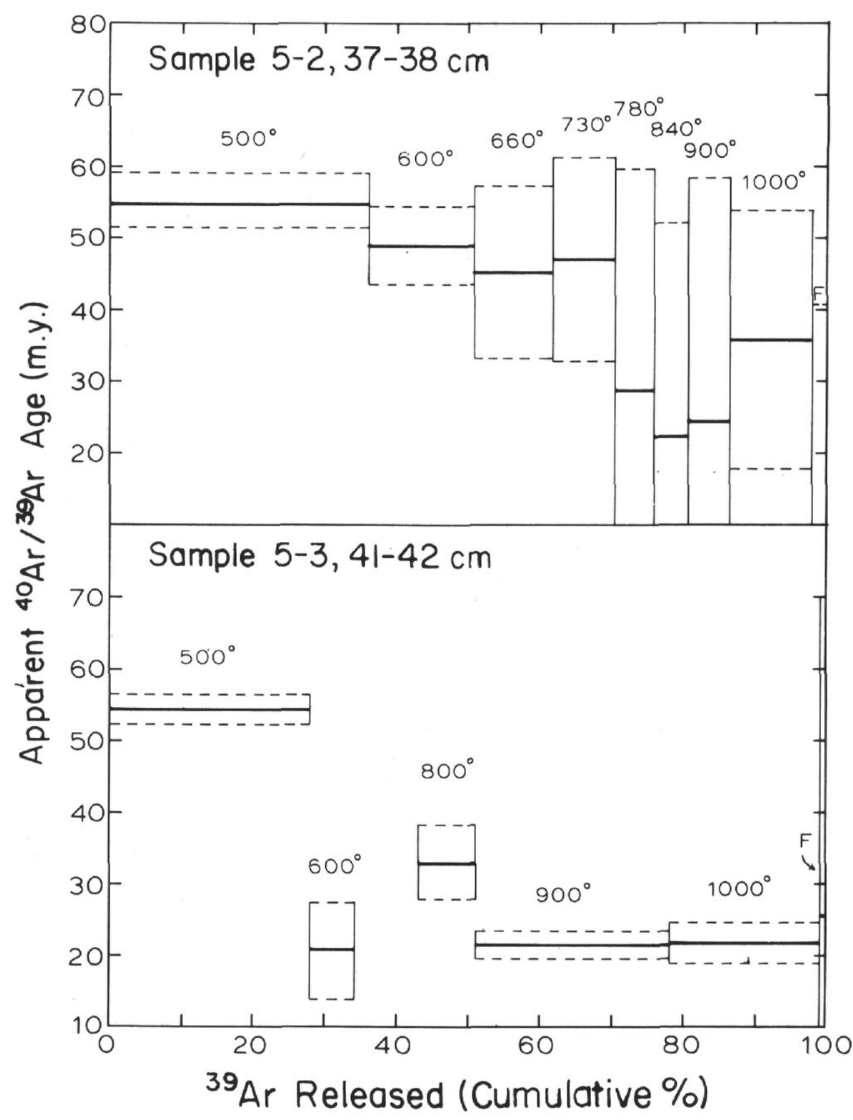

Figure 3. ${ }^{40} \mathrm{Ar} /{ }^{39} \mathrm{Ar}$ age spectra on basalt samples from DSDP Hole 192A, Meiji Guyot. Dashed lines indicate the estimated standard deviations about precision of the apparent ages (heavy lines). Temperatures are in degrees Celsius.

Stewart, R. J., Natland, J. H., and Glassley, W. R., 1973. Petrology of volcanic rocks recovered on DSDP Leg 19 from the North Pacific Ocean and the Bering Sea. In Creager, J. S., Scholl, D. W., et al., Initial Reports of the Deep Sea Drilling Project, v. 19: Washington (U. S. Government Printing Office), pp. 615-627.

van Hinte, J. E., 1976. A Cretaceous time scale, Am. Assoc. Petrol. Geol. Bull., v. 60, pp. 498-516.

Wood, D. A., Gibson, I. L., and Thompson, R. N., 1976. Elemental mobility during zeolite facies metamorphism of the Tertiary basalts of eastern Iceland, Contrib. Mineral. Petrol., v. 55, pp. 241-254.
Wood, D. A., Tarney, J., Varet, J., Saunders, A. D., Bougault, H., Joron, J. L., Treuil, M., and Cann, J. R., 1979. Geochemistry of basalts drilled in the North Atlantic by IPOD Leg 49: implications for mantle heterogeneity, Earth Planet. Sci. Lett., v. 42, pp. 77-97.

Worsley, J. R., 1973. Calcareous nannofossils Leg 19 of the Deep Sea Drilling Project. In Creager, J. S., Scholl, D. W., et al., Initial Reports of the Deep Sea Drilling Project, v. 19: Washington (U. S. Government Printing Office), pp. 741-750. 